\title{
Application of innovative materials in the construction of oil and gas processing facilities
}

\author{
Victoria Holodkova ${ }^{1, *}$, Yuri Ryabkin ${ }^{1}$, Mikhail Kostyshak ${ }^{2}$ and Alexey Tchaikovsky $^{3}$ \\ ${ }^{1}$ Saint-Petersburg State University, 62, Chaikovskogo street, 191123, Saint Petersburg, Russia \\ ${ }^{2}$ Moscow State University of Civil Engineering, 26 ,Yaroslavskoye Shosse, 109377, Moscow, Russia \\ ${ }^{3}$ Plekhanov Russian University of Economics, 36, Stremyanny lane, Moscow, Russia
}

\begin{abstract}
The article deals with the main aspects of construction of Bush sites in the difficult conditions of the far North. The main focus is on the effectiveness of the introduction of innovative technologies in the construction of road surfaces in such conditions with the use of nano-fiber concrete. A comparative calculation of the economic efficiency of using such technology with traditional ones is carried out.
\end{abstract}

\section{Introduction}

In the current economic conditions, the development of oil and gas field development sites, especially in the far North, which are caused by complex climatic, geological and geocryological conditions, requires the introduction of innovative technologies.

It should be noted that today a common option for developing oil fields is to organize them according to the cluster principle. This is due to the fact that when developing an oil field, it is very important to evenly move the extracted product.

As part of the technology for creating a Bush of oil wells, which is usually a special site. Such a site can form as a natural landscape, or be artificially created. As a rule, when creating an artificial site, they provide for the location of the wellhead at a distance of at least 50 meters from other bushes or single wells [1]. In addition, the composition of such a Deposit includes various types of technological equipment, engineering communications, as well as premises for customer service (household and office).

When creating such a field, one of the important factors in choosing a cluster placement option is the cost of organizing communications. The list of communications includes access roads, dumping sites, laying power lines, oil gathering, and so on. When organizing sites in this way, the cost of construction is significantly reduced [2]. It can also be noted that in addition to significant savings in capital costs, this also affects the environmental safety of such sites. One of the most important factors in the development of such a field is the construction of access roads, as well as roads that connect the objects of the field with each other. The use of special lightweight concrete or cellular gas-fiber concrete, which is a dry mixture of non-autoclave production, which is delivered in dry form to the construction site and only directly on the spot is diluted with water in the volume necessary for a specific operation, and then locally poured into the monolith.

* Corresponding author: doptaganka@yandex.ru 
The calculation of the efficiency of using this technology shows that a significant increase in the service life of the roadbed in conditions of alternating temperatures has a positive effect on the economic efficiency of such projects.

The investment component is the main component in the company's business development. Without it, any business will not be able to grow. Thus, the development of investment decision-making methods is due to the increasing needs for business development in the current economic conditions, as well as a number of uncertainties in the development and insufficient level of both technical and moral condition of the main investment sectors in Russia and, as a result, the need for their accelerated modernization $[3,4]$. Based on the data from the use of innovative technology, indicators of economic efficiency were calculated in comparison with traditional variants of road surface organization. In addition, the calculation took into account the service life of such a road surface, taking into account the replacement and repair of the surface over a long period of time. Road builders are well aware of the problem of construction on weak soils, which becomes the determining basis for the timing and cost of construction of the object.

One of the main factors in the destruction of roads, bridges, tunnels, sidewalks is frost heaving, which leads to destruction at subzero temperatures. Weak Foundation, one of the main other reasons for their destruction [5,6]. If the base is made in such a way that water can not come to the asphalt through its pores, the road will survive more than one winter, it will stand for decades without major repairs.

The use of special lightweight concrete or cellular gas-fiber concrete allows the production of innovative material for the construction of road surfaces in the form of a dry mixture of natural hardening.

When designing roads on weak soils, light concrete or cellular gas-fiber concrete can be used as a light fill of the embankment (light embankment) to ensure the stability of the base, reduce shrinkage and accelerate its achievement to the permissible value.

The properties of such concrete include the ability to increase in volume after mixing with water, which makes it possible to use the technology with high efficiency to fill karst and technological voids when laying tunnels, bridges, etc. [7,8]. The use of such concrete also makes it possible to significantly reduce the depth of soil freezing in road construction sites.

When creating an oil and gas field, you need to create access roads, as well as paths that connect the objects of the field with each other.

The use of light concrete in creating access roads, as well as paths that connect the objects of the field with each other, has a number of advantages:

- has a low weight (400-600 kg / m3) and is a monolith with sufficient strength;

- it is laid directly on the weak ground and creates a "pontoon" effect, on which the subsequent layers of road clothing are laid. Such a road has stability in seismic areas, and also provides insulation properties (capillarity, absence of frost heaving, reduction of ground freezing);

- capillary breaking-reduces the effect of moisture on the structure (frost heaving), thus creating a fairly rigid base, which increases the life of roads;

- protection in bad weather conditions-protects the base from softening during precipitation and when the soil freezes;

- reducing collateral damage. Compaction of loose materials can disrupt and weaken the Foundation soil. It is poured in liquid form, so there is no need to press or vibrate. [9-15]

It is assumed that the use of light concrete in road construction is carried out according to the following scheme (see Fig.1). 


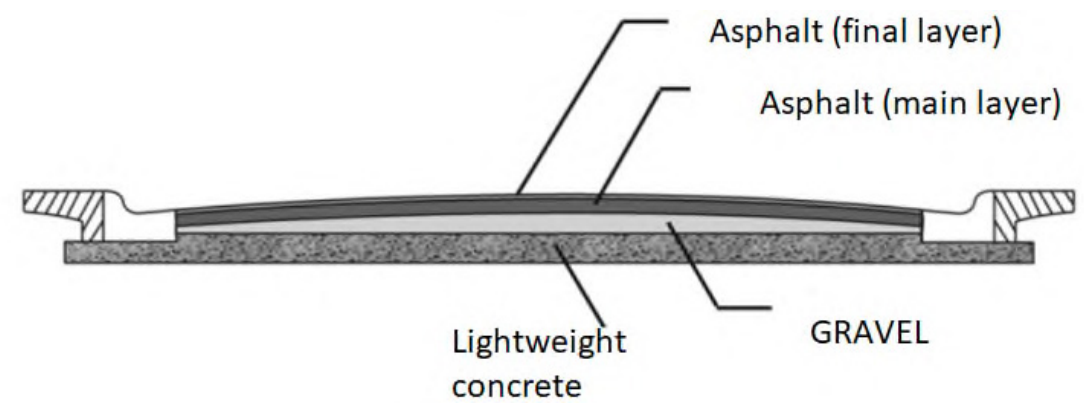

Fig. 1. Application of light concrete in road construction.

Figure 2. Shows the features of using light concrete in road construction, including the possibility of repairing the road surface.

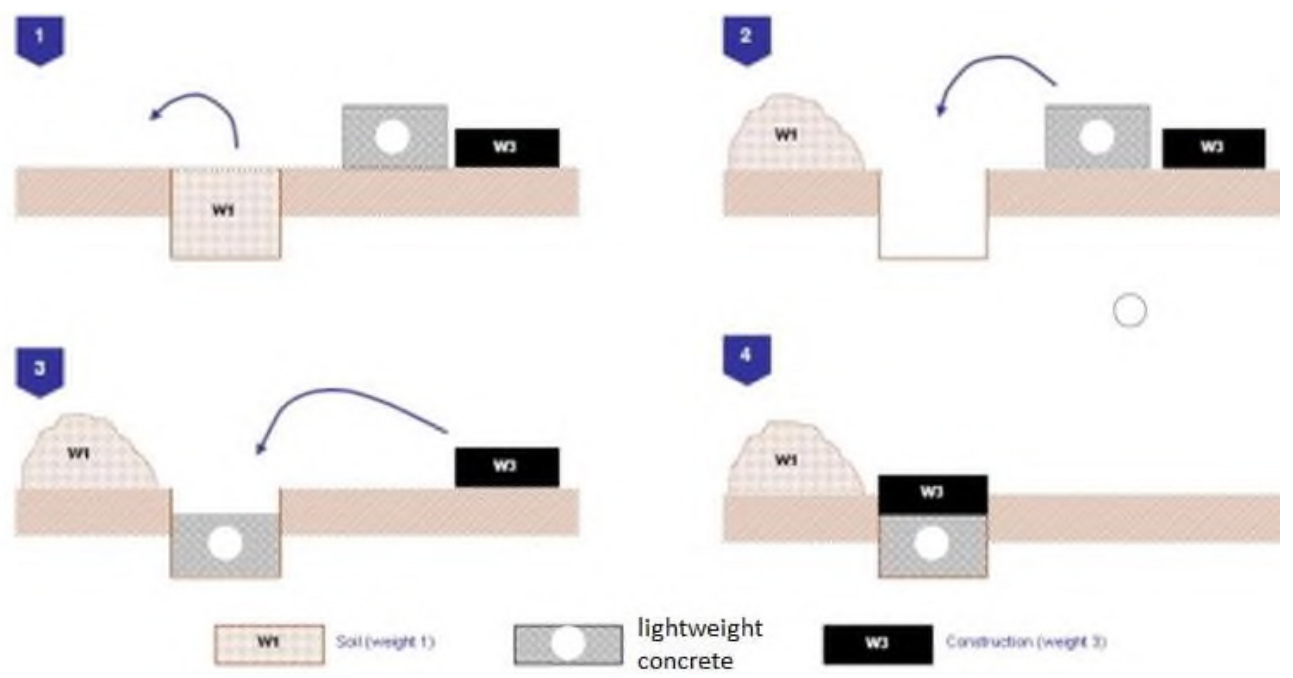

Fig. 2. The method of application of lightweight concrete in the construction of roads.

Note that we are talking about the serious advantages of this technology when using light concrete. The use of traditional technologies requires significantly more materials compared to creating a road surface of the same strength with the use of light concrete technology (see Fig. 3.).

\section{Traditional technology}

\section{Technology with the use of lightweight concrete}

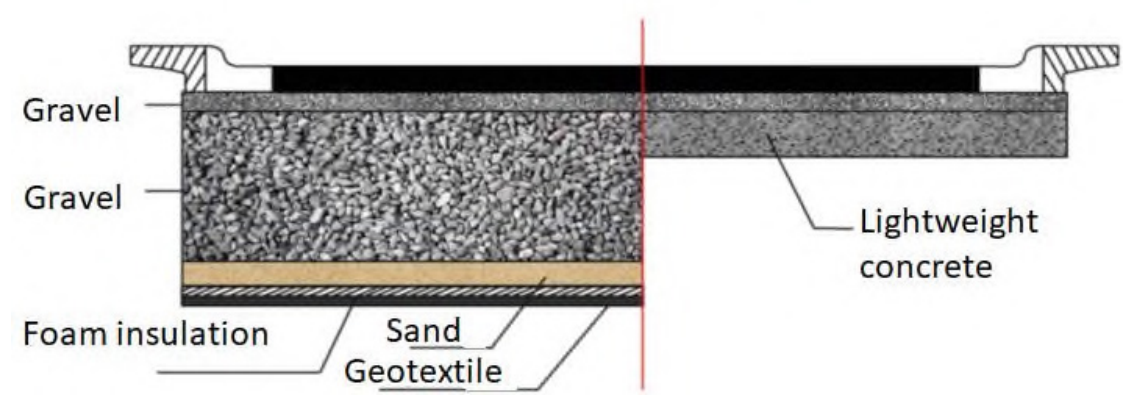

Fig. 3. Comparison of traditional road surface construction technology and light concrete technology. 
To analyze the economic indicators of roadbed construction options, let's compare two options for roadbed construction.

1. Traditional road clothing used on weak ground;

2. Construction of road pavement with the use of lightweight concrete.

In fact, the cost of materials, the location of quarries, the distance of transportation, prices for work, etc.vary in different regions, we will compare the volume of materials used per $1 \mathrm{~m} 2$ of road surface.

Table 1. Comparative analysis of the parameters of the construction of the roadway.

\begin{tabular}{|l|c|c|c|}
\hline \multicolumn{1}{|c|}{ Roadbed construction } & Thickness. $\mathbf{m}$ & $\begin{array}{c}\text { 1 type of roadbed } \\
\text { volume. } \mathbf{~ 3}\end{array}$ & $\begin{array}{c}\text { 2 type of roadbed } \\
\text { volume. } \mathbf{~} 3\end{array}$ \\
\hline Asphalt pavement & 0.125 & 0.125 & 0.125 \\
\hline Crushed stone base & 0.150 & 0.150 & 0.150 \\
\hline Rocky ground & 4.85 & 4.85 & Hет \\
\hline Lightweight concrete & 0.65 & HeT & $\mathbf{0 . 6 5}$ \\
\hline $\begin{array}{l}\text { Volume of selected soil } \\
\text { (peat) }\end{array}$ & & 5 & $\mathbf{0 . 9 5}$ \\
\hline
\end{tabular}

Note that this table did not take into account sheet piling, which is used only in the first case. The table shows that when using light concrete, the volume of removed soil (peat) is reduced by 5 times.

Here is an example of calculating the cost parameters of the roadbed and road surface of the projected highway "Karachaev - Nizhni Cherni" in the Kotelnikovsky municipal district of the Volgograd region according to four presented options.

Table 2. Comparative analysis of the parameters of the construction of the roadway.

\begin{tabular}{|l|c|c|c|}
\hline $\begin{array}{c}\text { Name of the roadway } \\
\text { construction variant }\end{array}$ & $\begin{array}{c}\text { On the 1st } \\
\text { kilometer of the } \\
\text { road, RUB. }\end{array}$ & $\begin{array}{c}\text { On the entire highway, } \\
\mathbf{1 0 . 8 3 6 6} \text { kilometers, RUB. }\end{array}$ & $\begin{array}{c}\text { Ratio of cost } \\
\text { indicators, \% }\end{array}$ \\
\hline $\begin{array}{l}\text { Option 1-road construction } \\
\text { using technologies of complex } \\
\text { strengthening and complex } \\
\text { stabilization of soils }\end{array}$ & $\mathbf{2 5 5 3 7 3 3 5}$ & $\mathbf{2 7 6 7 3 7 8 8 4}$ & $\mathbf{8 9 . 9 6 \%}$ \\
\hline $\begin{array}{l}\text { Option 2-combined road } \\
\text { construction }\end{array}$ & 27441746 & $\mathbf{2 9 7 3 7 5 2 5 7}$ & $\mathbf{9 6 . 6 7 \%}$ \\
\hline $\begin{array}{l}\text { Option 3-traditional road } \\
\text { construction }\end{array}$ & $\mathbf{2 8 3 8 8 0 4 1}$ & $\mathbf{3 0 7 6 2 9 8 4 5}$ & $\mathbf{1 0 0 \%}$ \\
\hline $\begin{array}{l}\text { Option 4-road wear with use } \\
\text { (light concrete) }\end{array}$ & $\mathbf{2 3 4 3 2 0 6 6}$ & $\mathbf{2 5 3 9 2 3 9 2 7}$ & $\mathbf{8 2 . 5 4 \%}$ \\
\hline
\end{tabular}

Taking into account the fact that the material is superior to foam concrete in its physical and mechanical properties, the service life and quality of road construction with the use of lightweight concrete technologies are significantly increased.

The advantages of lightweight concrete include:

\section{Water absorption-absolute moisture resistance of the material.}


Its use in the construction of various objects allows you to virtually eliminate expensive waterproofing. In addition, products made of such material do not require additional insulation.

\section{Environmentally friendly.}

This material is environmentally friendly, produced from sand, cement, fillers, pore forming agent, etc. It does not consume toxic substances, but its ecological value is second only to the tree. This, unlike wood, does not rot and does not age. The ecological purity of the raw materials used guarantees the complete safety of the products for the consumer. It is a porous material, so in residential / non-residential areas, its use is unlimited. The use of such a material in the precipitating elements creates the effect of a "thermos", i.e. it retains a fixed temperature.

\section{Energy saving}

The use of this material does not require complex steam power equipment, there is no need to attract special trained personnel energy Consumption of production is 2.5 times lower than autoclave. It should be noted that this characteristic is of great importance today when evaluating ongoing projects in the global economy.

\section{Sound insulation (db45)}

Due to the porous structure, the sound insulation properties of this material are 10 times higher than that of brickwork.

\section{Frost resistance (more than $50 \mathrm{~F}$ )}

Light concrete has an increased frost resistance of more than 50 cycles (for comparison, the frost resistance of heavy concrete is 50 cycles, bricks and gas silicate -35 cycles). This indicator is crucial when evaluating the durability of the material.

\section{Strength}

High strength of the material.

\section{Fire safety complies with SNiP 21-01-97}

This material is classified as non-combustible materials.

\section{Thermal insulation from $\mathrm{W} \mid \mathrm{MS}-0,07$}

The thermal resistance of enclosing structures made of light concrete material is 3 times higher than that of ceramic bricks and 8 times higher than that of heavy concrete.

In addition, as already mentioned, light concrete technology can be used in oil and gas production and processing facilities. Traditional backfill fillers for tanks include a layer of sand. This layer settles rises, crumbles. In these cases, corrective actions have to be taken.

Bases and backfill with the use of material are not subject to these disadvantages.

At oil and gas production and processing facilities, the technology can also be used to isolate pipelines, block wells, develop fields, fill voids, strengthen retaining walls, etc.

Table 3. Comparative analysis of material properties.

\begin{tabular}{|l|c|c|c|}
\hline \multicolumn{1}{|c|}{ Indicator } & Light concrete & Gas Silicate block & Foam Concrete \\
\hline Volume weight. kg / m3 & $300-1200$ & $400-600$ & $400-1200$ \\
\hline Strength kg / cm2 & $1-100$ & $25-35$ & $25-35$ \\
\hline $\begin{array}{l}\text { Coefficient of thermal } \\
\text { conductivity. } \lambda\end{array}$ & $0.08-0.16$ & $0.14-0.43$ & 0.3 \\
\hline $\begin{array}{l}\text { Frost resistance. cycle. } \\
\text { not less }\end{array}$ & 35 & 15 & 15 \\
\hline Sorption humidity. \% & $10-12$ & Дo 70 & $8-22$ \\
\hline $\begin{array}{l}\text { Water vapor } \\
\text { permeability. } \mu \text { possibility of a }\end{array}$ & $0.18-0.20$ & $0.11-0.23$ & $0.11-0.23$ \\
\hline $\begin{array}{l}\text { The pes } \\
\text { monolithic casting }\end{array}$ & yes & ye & yes \\
\hline Easy to process & & & yes \\
\hline
\end{tabular}


In addition, its use allows you to achieve a reduction in material costs, which reduces the weight of the structure, while sharply reducing the thickness of the road surface and its cost. Easy to use - it has a liquid consistency and is not affected by surface roughness.

We also note that based on research, this material fully complies with standards and other regulatory documents. Thus, the use of light concrete technology in the creation of such a deposit is one of the factors that significantly reduce the cost of construction and the cost of organizing communications.

\section{Referents}

1. V.D. Grebnev, D.A. Martyushev, G.P. Khizhnyak, Construction of oil and gas field facilities. Textbook (Perm. national research Polytech. UN-t., Perm, 2012)

2. A.B. Osokin, G.K. Smolov, A.S. Vitchenko, A.O. Vasilyeva, Proceedings of the fifth conference of geocryologists of Russia 1(3), 132-138 (2016)

3. S.E. Grechishchev, Thermal and mechanical processes in the development of minerals (Nauka, Moscow, 1964)

4. S.E. Grechishchev, Thermal and mechanical processes in the development of mineral (Nauka, Moscow, 1964)

5. A.P. Shevtsov, A.D. Vorontsov, V.Yu. Khokhlov, Yu.D. Merkulova, Optimization of resources and costs in the design of gas and oil and gas facilities using block-modular equipment UDC 624.01/.05:621:672:553.9

6. V.S. Tikhonov, T.P. Chaplygina, N.A. Zolin, Oil and Gas complex: problems and innovations: TEZ. II scientific and practical Conf. with international participation (Samara state technical University, Samara UN-t, 2017)

7. Abdikarimov, R., Khodzhaev, D., Vatin, N. To Calculation of Rectangular Plates on Periodic Oscillations. MATEC Web of Conferences. 2018. 245.

DOI:10.1051/matecconf/201824501003.

8. Akimov, L., Ilenko, N., Mizharev, R., Cherkashin, A., Vatin, N., Chumadova, L. MATEC Web of Conferences. 2016. 53. DOI:10.1051/matecconf/20165301022.

9. Al Ali, M., Isaev, S.A., Vatin, N.I. Development of Modified formulae for detection the welding stresses in the welded steel cross-sections. Materials Physics and Mechanics. 2016. 26(1). Pp. 9-15.

10. Arefiev, N., Mikhalev, M., Zotov, D., Zotov, K., et al, Procedia Engineering. 2015. 117(1). Pp. 32-38. DOI:10.1016/j.proeng.2015.08.120.

11. Baiburin, A.K., Rybakov, M.M., Vatin, N.I. Heat loss through the window frames of buildings. Magazine of Civil Engineering. 2019. 85(1). Pp. 3-14.

DOI:10.18720/MCE.85.1.

12. Barabanshchikov, Y., Fedorenko, I., Kostyrya, S., Usanova, K. Advances in Intelligent Systems and Computing. 2019. 983. Pp. 858-866. DOI:10.1007/978-3-030-198688 84.

13. Benin, A., Konkov, A., Kavkazskiy, V., Novikov, A., Vatin, N. Procedia Engineering. 2016. 165. Pp. 1483-1489. DOI:10.1016/j.proeng.2016.11.883.

14. D. Khodzhaev, B. Normuminov, Y. Mustapakulov, A. Mottaeva, E3S Web of Conferences 110, 01045 (2019) doi.org/10.1051/e3sconf /201911001045

15. V.V. Holodkova, Investment project management: textbook and practical course for academic baccalaureate (URAIT Publishing house, Moscow, 2018)

16. G. Kozlov, M. Pushkarev E3S Web of Conferences 135, 01053 (2019) doi:10.1051/e3sconf/201913501053 